\title{
Stock market development and agricultural growth of emerging economies in Africa
}

\author{
Chi Aloysius Ngong and Kesuh Jude Thaddeus \\ Banking and Finance, University of Nigeria, Nsukka, Nigeria \\ Lionel Tembi Asah \\ Economics and Applied Management, University of Douala, Douala, Cameroon, and \\ Godwin Imo Ibe and Josaphat Uchechukwu Joe Onwumere \\ Banking and Finance, University of Nigeria, Nsukka, Nigeria
}

Stock market development

\begin{abstract}
Purpose - This research investigates the bond between stock market development and agricultural growth in African emerging economies from 1990 to 2020.

Design/methodology/approach - Agricultural value added to the gross domestic product measures agricultural growth and market capitalization and stock value traded measure stock market development.

Findings - The findings disclose that market capitalization negatively affects agricultural growth while stock value traded positively affects agricultural growth in the fully modified and dynamic ordinary least square techniques. The findings unveil bidirectional causality between labour and agricultural value added with unidirectional causality flow from agricultural value added to market capitalization and stock value traded.

Research limitations/implications - The governments should promote agricultural growth initiatives which stimulate stock market development. Effective methods required to encourage credit flow to the agricultural enterprises through the stock markets' intermediation should be promoted using aggressive policies which eliminate credit flow bottlenecks. Policy makers and regulatory authorities should implement policies which attract investors to the agricultural sector and encourage companies' listing in the stock markets. The capital market funding should be expanded to boost economic growth through agricultural value added.

Originality/value - Literature reveals divergent results on the relationship between stock market development and agricultural growth. Earlier studies provide conflicting findings on the bond between stock market development and agricultural growth. Some findings indicate positive link between stock market development and agricultural growth, while others show a negative association. Studies' results reveal opposing directions of causality between stock market development and agricultural growth.
\end{abstract}

Keywords Stock market, Agricultural growth, Emerging economy, FMOLS, DOLS

Paper type Research paper

\section{Introduction}

Generally, studies have been carried out on the association between financial development and economic growth in developing countries. A majority of the studies focused essentially on banking sector development to measure financial development. Specifically, studies that address the dynamic affiliation between stock market development and the different economic sectors' growth are limited. Furthermore, the results on the relationship between

(C) Chi Aloysius Ngong, Kesuh Jude Thaddeus, Lionel Tembi Asah, Godwin Imo Ibe and Josaphat Uchechukwu Joe Onwumere. Published in Journal of Capital Markets Studies. Published by Emerald Publishing Limited. This article is published under the Creative Commons Attribution (CC BY 4.0) licence. Anyone may reproduce, distribute, translate and create derivative works of this article (for both commercial and non-commercial purposes), subject to full attribution to the original publication and authors. The full terms of this licence may be seen at http://creativecommons.org/licences/by/4.0/ legalcode. 
JCMS 6,2

186 stock market development and agricultural growth are debatable. Empirical evidence reveals that the findings between the stock market development and agricultural growth differs in each location over time. The capital market is a structure of institutions which provide long run financial assets and instruments like shares, stocks, debentures, mortgages, etc. (Alile and Anao, 1986). A capital market arranges additional channels to engage and mobilize domestic savings for investment productivity (Olowe, 2011).

The stock market is a market that deals with lending and borrowing of long-term funds (Ekezie, 2002). The stock market presents a meeting point for lenders and borrowers. Each stock market directs funds from the surplus to deficit sectors in an economy to ensure development. Capital markets play a financial intermediation function in each economy. The value exchange is in the form of long-term cash securities where the borrowers and governments issue financial instruments to the lenders. The securities could be shares, bonds, debentures and stocks. The shares are sometimes called equity instruments, while other securities are described as debt instruments (Ekezie, 2002). A stock market ensures the buying and selling of long-term debt or equity securities (Abdulahi, 2005). The African financial markets are becoming highly complex thus the stock markets' significance need not be overemphasized. The stock markets promote growth via several channels like liquidity creation, savings mobilization for the private and public sectors, risk diversification and quality information dissemination (Shittu, 2012). With these services delivery, the agricultural growth is enhanced. In emerging economies, the growth of stock markets reliably increases over the years. Pardy (1992) posited that in developing countries, the capital markets mobilize savings domestically and distribute funds efficiently. The stock markets stimulate developing countries' economic growth through investment attraction and redirection. The capital market finance which provides long-term investment funds is the best option to finance agriculture as accelerates agricultural development which engenders economic growth (Agbaeze and Onwuka, 2013).

The importance of stock markets on agricultural growth is as follows: First, stock market performance and development increase the savings proportion which is funnelled to investments. Second, stock markets development motivates the savings rate which in turn encourages investments. Third, stock market development increases the capital allocation efficiency. The uses confined into the savings-investment conversion from stock market and the agricultural activities in an economy. The stock market mobilized savings are efficiently converted into productive investments in the different economic sectors (Edame and Okoro, 2013). Agriculture-led growth was crucial in diminishing poverty and transformed many Asian and Latin American countries' economies positively but the hypothesis did not hold true in Africa. The notion that the agricultural sector plays only a passive role in development was dismissed by the dynamism of the Asian green revolution in the late 1960s and early 1970s. The traditional agriculture transformation into a modern agricultural sector indicated the agricultural growth potential (Hayami and Ruttan, 1985). Agricultural growth in African still lags behind compared to the rest of the world. This limitation creates scepticism in the international community development on the relevance of agriculture growth and poverty reduction. Some countries in Africa are disadvantaged in agricultural growth and development due to unfavourable natural and geographical conditions. The low agricultural growth is largely due to underinvestment in physical, institutional and human capital (World Bank, 2018).

Given that agricultural output forms a large proportion of total national output and provides jobs a majority of the population in emerging countries, the sector forms an integral part of economic development. The role of agriculture in growth and development changes considerably over time. The classical theory considers economic development to be a growth process with systematic reallocation of productive factors from a primary sector with low productivity, technology and output to a modern industrialized sector with superior 
productivity and returns (Adelman, 1984). Changing from the traditional to modern economies currently, agricultural growth remains highly essential for economic transformation and development. Agriculture has two key characteristics which justified importance in economic development. First, agriculture produces goods which directly satisfy the basic human needs in an economy. Second, agricultural growth uses human effort with natural resources like land and agro-ecological assets to improve livelihood (FAO, 2018).

Currently, limited access to finance remains a key factor which prevents agricultural modernization in African emerging economies. Hence, the need to design financing frameworks adapted to the specificities of agriculture and consistent with the demands of rural financial markets (World Bank, 2018). This necessitates research and the attainment of the Food and Agriculture Organization's Sustainable Development Goals (SDGs) of hunger eradication, food security and nutrition by 2030 using agricultural finance via stock market in Africa (FAO, 2018).

In 2017, roughly 821 million people globally still lack sufficient food to eat and live an actively healthy life, about one out of nine persons. Additionally, statistics from the Food Insecurity Experience Scale (FIES) indicate that about $10 \%$ of the global population is exposed to abject food insecurity, which are about 770 million people. The frequency rate of world undernourishment improved from $13.1 \%$ in 2007 to $10.9 \%$ in 2017 , while the prevalence rate of severe food insecurity worsen from $8.9 \%$ in 2016 to $10.2 \%$ in 2017 (FAO, 2018).

African countries are beginning to recognize the need to engage in agriculture after decades of inattentive policies, poor taxation and limited investment opportunities. The Maputo Declaration by the African Union (AU, 2003) ordered for $10 \%$ investment of countries' budgets into agriculture and reinvest $6 \%$ annual growth rate of agriculture. Also, the Malabo Declaration dwelled on the previous declaration and prescribed a double agricultural productivity growth (AU, 2014). The policies for improving yields per hectare using modern seeds and sufficient fertilizer are appreciated. More policies are needed in expanding credit to rural areas (Zedillo, 2015). The FAO estimates that the investments required in emerging countries to sustain the agricultural growth exceed the current food demand trends. The challenging issue is to increase capital stocks needed for investments to boost agricultural productivity and reduce hunger (FAO, 2019). Equally, to satisfy humans' basic needs implied that agricultural growth should match population growth to following the Malthusian population hypothesis (Diao et al., 2007). A balanced growth is a strategy for national development of agriculture as the primary sector which provides raw materials to the industries (Singer, 1979). The strategy emphasizes that an increase in agricultural productivity expands the internal demand for consumer goods from domestic industries which drives toward industrialization (Adelman, 1984). Therefore, it is necessary to ensure agricultural growth sustainability.

\section{Literature review}

\subsection{Theoretical review}

2.1.1 Endogenous growth theory. The endogenous growth theory was propounded by Robert Solow and Trevor Swan in 1956. The theory is also referred to as the Solow-Swan model. This theory explains that endogenous growth results from a combination of capital, labour and technology. This theory elucidates that stock market proxies like market capitalization, all-share index, number of listed equities, number of deals, value of deals, value of transactions and stock market turnover apply a considerable effect on agricultural growth. The variables measure the capital market efficiency, funds mobilization, liquidity and wealth creation capacity (Ayodeji and Ajala, 2018).
Stock market development 
JCMS

6,2

188
2.1.2 Information asymmetry hypothesis. This theory was propounded by Eugene Fama in 1970. The theory is applied in line with Akerlof et al. (1970) where only few persons among the parties involved in a transaction have the accurate and full information, whereas the other parties have residual information. The parties are stock market participants and farmers. Information asymmetry may originate from the farmers who conceal information on the effective purpose of their activities and the intended use of borrowed funds. It could also emanate from the stock markets dealers when they forecast lucrative returns from agricultural output and lure the farmers into future or forward contracts with credit. However, banks sometimes lend money to agricultural investors at high interest rates to alleviate the problem of information asymmetry.

2.1.3 Theory of moral hazard. This theory was propounded by Akerlof (1970) and subsequently upgraded by Rothschild and Stiglitz (1976). The theory postulates a situation where the possibility of loan default increases when borrowers fail to reveal the genuine purpose of the borrowed funds. The theory stipulates that farmers intentionally conceal the purpose of their borrowing from the banks. Moral hazard occurs as a result of dominance of large and wealthy landholders who obtain cheap credit since they possess more resources to offer as collateral and as a result the poor borrowers are left out (Simtowe et al., 2006). Arrow (1963) stated that moral hazard is the phenomenon of exploiting private information to gain advantage in an incomplete contract during information asymmetry. Musara and Olawale (2012) equally posited that moral hazard manifests where the bank borrowers take actions that negatively impact the banks' returns.

2.1.4 Adverse selection theory. This theory was propounded by Akerlof (1970) and later upgraded by Rothschild and Stiglitz (1976). The theory demonstrates a situation where the probability of loan default increases when interest rate increases. Also, the quality of borrowers gets worsened with the increase in borrowing cost (Musara and Olawale, 2012). Adverse selection occurs in the credit markets when the formal credit institutions are not fully aware of borrower's credit worthiness. Therefore, some credits worthy borrowers are left out when the credit market try to mitigate the risk of default by raising the rate of interest (Binswanger and Deininger, 1997; Ghosh et al., 2000; Klonner and Rai, 2005). The theory of adverse selection implies that lenders can misjudge the activities of agricultural investor and farmers hence finance the wrong person instead of the right one. The adverse selection theory implies a situation, whereby the lenders do not know the real action, borrower's asset and the situation where the lender knows everything about one borrower's activities but cannot verify it. The use of high interest rate equally remedies the adverse selection where a choice is made between riskier and risk projects. The trustworthy clients are disfavoured at the expense of the unscrupulous ones (Stiglitz, 1998).

\subsection{Empirical review}

Bashorun and Bakare-Aremu (2013) examined the relationship between capital market development and economic growth in Nigeria from 1981 to 2011 using co-integration and error correction model techniques. Economic growth was proxied by real gross domestic product (GDP), while capital market development was measured by market capitalization, allshare index and number of deals. The findings showed that all-share index, number of deals and market capitalization positively and significantly impacted economic growth. Also, unidirectional causality ran from capital market to economic growth with feedback causality between market capitalization and economic growth. Obiakor (2016) estimated the capital market-economic growth nexus in Nigeria - Africa's largest economy from 1985 to 2015 employing ordinary least squares method of analysis. Economic growth was proxied by GDP, while capital market indicators were market capitalization, value of transactions and all-share index. The findings showed that the market indices heterogeneously affected 
Nigerian economic growth. Also, the results revealed that capital market development significantly promoted economic growth.

Sehrawat and Giri (2017) investigated the role of sector analysis of stock market development on Indian economic growth from 2003Q4 to 2014Q4 using autoregressive distributed lag model. The study used three different dependent variables namely: manufacturing sector share of GDP, electricity, gas and water sector share of GDP and service sector share of GDP. Crude oil price, real exchange rate, T-bill rates, trade openness and wholesale price index were control variables. The findings unveiled a long and short-runs affiliation between sector-specific GDP and sector-specific stock indices. Unidirectional causality flowed from sector-specific stock prices to their respective sector's GDP. Ayodeji and Ajala (2018) estimated the contributions of capital market performance to Nigerian economic growth from 1984 to 2016 using ordinary least squares, autoregressive distributed lag and vector autoregressive techniques. Economic growth was measured by GDP, while capital market performance was proxied by market capitalization, all-share index, number of listed equities, number of deals, value of deals, value of transactions and stock market turnover. The findings showed that market capitalization, number of listed equities and value of transactions positively contributed to economic growth. Stock market turnover, all-share index, number of deals and value of deals negatively contributed to economic growth. Uwajumogu et al. (2013) investigated the capital market growth-induced impact on agricultural sector in Nigeria from 1980 to 2012 using co-integration approach. The study agricultural sector was measured by agricultural growth rate and capital market was proxied by market capitalization ratio and all-share index. Electricity, inflation rate and gross capital formation were control variables. The results indicated that market capitalization ratio and all-share index statistically and insignificantly affected Nigerian agricultural output in the long run.

Agbaeze and Onwuka (2013) estimated capital market option to finance agriculture in Nigeria adopting a qualitative research design. The findings showed that economic down turn shifted the tide of economic policies and research focus towards agriculture. The oil sector retrogressive earnings performance highlighted the need for economic diversification alongside the revenue base. Ibi et al. (2015) examined the effect of capital market performance on industrial sector development in Nigeria from 1980 to 2012 using co-integration test, granger causality test and error correction mechanism. The industrial sector development was measured by industrial output while capital market proxies were market capitalization, number of deals and value of transactions. The GDP and exchange rate were control variables. The findings showed that a long-run equilibrium affiliation between capital market and industrial output. Bidirectional causality existed between market capitalization and industrial output and between number of deals and industrial output. Unidirectional causality ran from value of transactions to industrial output. The market capitalization and number of deals had significantly positive effects on industrial output, while value of transactions had significantly negative effects on industrial output.

Offum and Ihuoma (2018) estimated the direction of causality between capital market and industrial performance in Nigeria from 1985 to 2015 using Granger causality test. Industrial performance was measured by industrial sector share of GDP, and capital market was proxied by market capitalization ratio and total value of shares traded. The share of education recurrent expenditure on GDP and domestic investment share of GDP controlled the analysis. The results unveiled a unidirectional causality migration from market capitalization ratio and total value of shares traded ratio to GDP. Ini and Eze (2019) estimated the implications of stock market efficiency on manufacturing sector performance in Nigeria from 1985 to 2017 using regression analysis. Manufacturing sector performance was proxied by the ratio of manufacturing sector value added to GDP while stock market efficiency used all-share index as proxy. Inflation rate and exchange rate served as control variables.
Stock market development 
JCMS 6,2
The findings indicated that all-share index significantly and negatively affected manufacturing sector performance. The manufacturing sector in Nigeria faces low output and economic instability.

Eze et al. (2019) investigated the effects of stock market liquidity on Nigerian manufacturing sector performance from 1981 to 2017 using autoregressive distributed lag technique. The manufacturing sector performance was measured by manufacturing sector output, while stock market liquidity utilized market capitalization ratio and allshare index (ASI) as proxies. Interest rate and exchange rate were applied as control variables. The findings revealed that market capitalization ratio to GDP insignificantly and positively affected the manufacturing sector performance. All-share index significantly and positively affects manufacturing sector output. Ayodeji and Ajala (2019) investigated the effect of capital market performance on sectors' output growth in Nigeria from 1984 to 2018 using autoregressive distributed lag model. Capital market performance used all-share index (ASI), number of listed equity, market capitalization, and number of deals, stock market turnover, value of deals (NOD) and value of transactions (VTRAN) as indicators. The sectors' output growth were contribution of agricultural sector to GDP, contribution of industrial sector to GDP, contribution of construction sector to GDP, contribution of trade sector to GDP and contribution of service sector to GDP. The findings revealed that all-share index, market capitalization ratio (MCAP), value of transactions and number of listed equities had significantly positive effects on agricultural sector output in long-run. MCAP and NOD had significantly positive effects on industrial output in long-run. MCAP significantly and positively affected the construction sector output in long-run. MCAP had significantly positive impact on trade sector output in while ASI, VTRAN and NOD insignificantly and positively affected the trade sector output in long run.

Owen (2020) examined the relationship between stock market development and Nigerian economic growth from 1985 to 2018 applying the ARDL bound test method. Economic growth was proxied by GDP and turnover ratio, market capitalization ratio and value of share-traded surrogated stock market development. Money supply captured the monetary sector financial innovations. The results unveiled a long-run relationship between stock market development and economic growth. A statistically insignificant positive relationship existed between stock market development indices and economic growth. Ikikii and Nzomoi (2013) investigated the effect of stock market development on economic growth in Kenya from 2000Q1 to 2011Q4. The GDP proxied economic growth while market capitalization and trade volume measured stock market development. The results indicated that trade volume and market capitalization impacted positively on Kenyan economic growth.

Okoye and Nwisienyi (2013) examined the impact of stock market on Nigerian economic growth from 2000 to 2010 using ordinary least squares techniques. The results showed that all-share index, market value and market capitalization significantly impacted on economic growth. Khetsi and Mongale (2015) investigated the impact of capital markets on South African economic growth from 1971 to 2013 applying co-integration and Granger causality tests. The results revealed that market capitalization and value of transactions positively impacted economic growth. Osakwe and Ananwude (2017) examined the relationship between stock market development and economic growth in Nigeria and South Africa from 1981 to 2015 using ARDL co-integration techniques. The GDP growth rate measured economic growth, while market capitalization ratio and stock value traded ratio surrogated stock market development. The results unveiled a long-run equilibrium relationship between stock market development and economic growth in Nigeria but not in South Africa. A positive insignificant relationship existed between stock market development and economic growth in Nigeria and South Africa in the short and long runs. The results indicated that market capitalization in South Africa significantly affected economic growth but not in 
Nigeria. Insignificant variations on economic growth from stock market development indices were observed in Nigeria and South Africa.

Karim and Chaudhary (2017) investigated the effect of stock market development on economic growth of South and East Asia from 1996 to 2015 using panel linear regression. Market capitalization, total value traded ratio and turnover ratio measured stock market development, while GDP per capita growth rate measured economic growth. The findings showed that stock market development significantly affected the economic growth of South Asia but non-significantly impacted East Asian economic growth. Owusu (2018) estimated the relationship between stock market development and economic growth in South Africa applying autoregressive distributed lags-bounds test approach. The findings showed that stock market development minimally impacted economic growth in the long run. Stock market development strongly impacted South African economic growth in the short run.

Abera et al. (2019) estimated the impact of stock market performance on South African firm's growth from 2001Q1 to 2015Q4 employing Johansen's co-integration and vector error correction model techniques. The results indicated that stock markets performance significantly impacted firms' growth in the long run. Chukwuemeka and Boma-Oruwari (2021) investigated the direction of causality between stock market development and stock prices in Nigeria using co-integration, granger causality test and vector error correction model. The aggregate stock price percentage of GDP was the endogenous variable, while money supply ratio, financial market competition, net domestic deposits ratio and financial market efficiency proxied stock market development. The findings showed that $72 \%$ of the variations in the aggregate stock price was explained by the predictor variables. Financial market competition positively and non-significantly affected Nigerian aggregate stock price. Financial market access positively and significantly affected aggregate stock price, while financial market efficiency negatively and significantly affected aggregate stock price. Financial market scope positively and significantly affected aggregate stock price.

Osamwonyi and Kasimu (2013) investigated the direction of causality between stock market development and economic growth in Ghana, Kenya and Nigeria from 1989 to 2009 with Granger causality test. The stock market development was proxied by market capitalization (MC), stock turnover ratio (STO), stock traded value (TVL), number of listed securities (LS) and stock market index (MI), while real GDP proxied economic growth. The findings showed that no direction of causality existed between stock market development and economic growth in Ghana and Nigeria. A bidirectional causal link existed between stock market development and economic growth in Kenya. MC and LS Granger caused economic growth in the three countries while bidirectional causality existed between STO and GDP. TVL had a significantly negative effect on economic growth.

Although the agricultural sector's potentials as a critical engine in economic growth are really compelling, literature reveals divergent results on the relationship between stock market development and agricultural growth. There is no clear direction of causality between stock market development and agricultural growth. The earlier studies conducted used different methodologies. The studies provide non-consensus findings on the bond between stock market development and agricultural growth. Some findings indicate positive link between stock market development and agricultural growth (Karim and Chaudhary, 2017; Okoye and Nwisienyi, 2013), while others show a negative association (Ayodeji and Ajala, 2018; Ini and Eze, 2019). There are results which reveal no direction of causality between stock market development and agricultural growth (Osamwonyi and Kasimu, 2013) and others suggest bidirectional causality (Bashorun and Bakare-Aremu, 2013). Some findings show unidirectional causal link between stock market development and agricultural growth (Ibi et al., 2015; Offum and Ihuoma, 2018). Additionally, limited panel studies have been conducted on the relationship between stock market development and agricultural growth in African emerging economies. The conducted studies give inconclusive findings which
Stock market development 
JCMS

6,2

192 motivate further research. Thus, this study examines the causation between stock market development and agricultural growth in emerging economies in Africa.

\section{Data and methodology}

The necessary pre- and post-diagnostic checks like descriptive statistics, unit root, crosssectional dependence test, Hausman test inherent in panel data estimations, Wald and normality tests are performed to justify the parameters' properties. The various LM tests employed in this study include Breusch and Pagan (1980), Pesaran (2004), CD, Pesaran (2004) scaled and Baltagi and Badi (2012) bias-corrected scaled. The Levin et al. (2002), Im et al. (2003) tests are used for the panel unit roots to establish the series stationarity. The Levin et al. (2002) test assumes an identically common unit root test process with cross sections, and Im et al. (2003) ensures the units cross-sectional independence. The variables applied in this study comprise of agricultural value added to the GDP, market capitalization, stock value traded, broad money supply ratio, physical capital and labour. The choice of variables is defined by data availability while considering multicollinearity and parsimonious model. African emerging economies' annual secondary data are gleaned from the International Monetary Fund and world development indicators from 1990 to 2020. The economies consist of Botswana, Egypt, Ghana, Kenya, Mozambique, Nigeria, South Africa, Tanzania, Tunisia, Uganda and Zambia based on the International Monetary Fund country ranking (IMF, 2020). Agricultural value added (AGRVA) to GDP is the measure for agricultural growth. Market capitalization (MCAP) and stock value traded (SVT) are proxies for stock market development. The broad money supply ratio $\left(M_{2} / \mathrm{GDP}\right)$, physical capital (PHKAP) and labour (LAB) are control variables. This study verifies the interactive relationship between the exogenous variables and endogenous variable. The nexus of stock market development and agricultural growth in African emerging economies is estimated with co-integration and Granger causality tests.

\subsection{Method of estimation}

This study applies pre-tests like descriptive statistics, unit root test, correlation, crosssectional dependence, Hausman test before co-integration tests employing the fully modified ordinary least squares (FMOLS), dynamic ordinary least squares (DOLS) and Granger causality to establish the long-term association among the variables. The FMOLS is a nonparametric approach used to check serial correlation when variables are integrated of order one I(1) (Philip and Hansen, 1990). This FMOLS technique gives reliable estimates with small sample size and robust results. The FMOLS technique is superior to the ordinary least squares and Engle-Granger methods by appropriately correcting the inference problems in both methods. Thus, ensures validity of the long-run estimates (Himansu, 2007). The FMOLS method uses the Kernal estimators of the disturbance parameters on the asymptotic distribution of the ordinary least squares estimator. To attain asymptotic efficiency, the FMOLS method corrects the serial correlation effects and checks the regressors' endogeneity to ensure that co-integration exists (Rukhsana and Shahbaz, 2008). The DOLS is a parametric approach in which lags and leads are applied to take care of the problem of correlation among variables irrespective of the integration order of variables, I(0) or I(1) and the existence or absence of co-integration (Stock and Watson, 1996). The DOLS technique corrects endogeneity problems and provides unbiased co-integrating coefficients estimates due to its dynamic nature (Inagaki, 2010). The FMOLS and DOLS provide a check for results' robustness. The panel unit root test is fragmented into 1st and 2nd generations (Hossfeld, 2016). The prominent 1st generation panel unit root tests include Levin et al. (2002) and Im et al. (2003). Basically, the tests are derived from the routine augmented Dickey-Fuller (ADF) 
unit root check in time series analysis. However, an assumed cross-sectional independence exists. The random process $y_{\mathrm{t}}$ in the one variable $\mathrm{ADF}$ unit root test approximates the model:

$$
\Delta y_{t}=\rho y_{t-1}+\sum_{p=1}^{p} \varphi_{p} \Delta y_{t-p}+\gamma_{\lambda} D_{l}+\varepsilon_{t}, t=1, \ldots, T
$$

With $D_{1}$, being $l=\{1,2,3\}$ which stand for a vector term, that indicates if the technique uses none, intercept without time trend or intercept and time trend jointly. With ADF statistics, the null hypothesis that the series has a unit root and the alternative that the series has stationarity is verified. Hence, $\mathrm{H}_{0}: \rho=0, \mathrm{H}_{1}: \rho<0$. The ADF panel testing estimates the equation:

$$
\Delta y_{i, t}=\rho_{i} y_{i, t-1}+\sum_{p=1}^{p i} \varphi_{p i} \Delta y_{i t-p}+\gamma_{i l} D_{i l}+\varepsilon_{i t}, t=1, \ldots, T, i=1, \ldots, N
$$

This research adapted the Cobb-Douglas production function for the model approximation from Abeka et al. (2021). Frequently, growth analysis applies the Cobb-Douglas endogenous growth production model with two variables perceived to be output scaled fixed. From Abeka et al. (2021), Makki and Somwaru (2004), the function is presented as shown below before other variables are integrated:

$$
G_{i t}=A K_{i t}^{\alpha} L_{i t}^{\beta} e^{\mu_{i t}}
$$

where $G$ denotes agricultural growth, $A$ is the constant term, $K$ denotes fixed capital and $L$ represents labour supply. $\alpha$ and $\beta$ are the respective coefficients of capital and labour with values ranging between 0 and 1 , implies $0<\alpha, \beta<1 . i$ denotes the countries, $t$ is time period and $\mu$ is error term. Given that this research examines the causation between stock market development and agricultural growth, integrating stock market variables in Model (3) gives Model (2) as follows:

$$
A G R V A_{i t}=\beta_{0} M C A P_{i t}^{\alpha} S V T_{i t}^{\beta} \frac{M_{2}}{G D P_{i t}^{\gamma}} P H K A P_{i t}^{\psi} L A B_{i t}^{\varphi} e^{\mu_{i t}}
$$

With $\alpha, \beta, \gamma, \psi$ and $\varphi$ are the respective coefficients of market capitalization, stock value traded, broad money supply ratio, capital and labour, respectively. The coefficients' values fluctuate between 0 and 1, i.e. $0<\alpha, \beta \gamma, \psi, \varphi<1$. $\beta_{0}$ is the intercept of the model. $\log$ linearising Eqn (4) produces Eqn (3) as:

$$
\begin{aligned}
\ln A G R V A_{i t}= & \beta_{0}+\alpha \ln M C A P_{i t}+\beta \ln S V T_{i t}+\gamma \ln \frac{M_{2}}{G D P_{i t}}+\psi \ln P H K A P_{i t}+\varphi \ln L A B_{i t} \\
& +\pi_{i t}+\mu_{i t}
\end{aligned}
$$

Here, $\ln A G R V A_{i t}$ stands for agricultural growth; $\ln M C A P_{i t}$ is market capitalization, $\ln S V T_{i t}$ is stock value traded, $\ln M_{2} / G D P_{i t}$ represents broad money supply ratio, $\ln P H K A P_{i t}$ denotes gross capital formation, $\ln L A B_{i t}$ is labour supply, $\pi_{i t}$ indicates the country-specific effects in the panel units and $\mu_{i t}$ is the error term. The theoretical explanation of variables is as follows: Market capitalization ratio is described as the value of listed companies operating on the stock exchange market as a percentage of the GDP (Ayodeji and Ajala, 2018). The stock value traded refers to the total value of shares traded between sellers and buyers in the stock market within a given period (Beck and Levine, 2004). Broad money supply ratio is the total 
JCMS

6,2

194

quantity of currency exterior the banks like demand deposits, savings and foreign currency deposits which are not from the central government, bank and traveller's cheques including securities certificates and commercial papers (World Bank, 2020). Broad money supply ratio measures the efficiency of the stock market development based on the velocity of money in circulation in an economy. Physical capital is calculated from gross fixed capital consumption. Fixed capital consumption refers to the substituted value of capital used in the production process (World Bank, 2020). Labour force consists of total labour force of people aged 15 years and above who provide the work force for the production of goods and services within a specified time frame (World Bank, 2020).

\section{Discussion of results}

\subsection{Descriptive statistics}

The mean, maximum, minimum and standard deviations values from Table 1 are used to reliably robust check the results. The series normality level is estimated using the skewness, kurtosis and Jarque-Bera probability values. The descriptive statistics values reveal that the mean AGRVA value for each nation ranges from 1.8283 minimum to 44.824 maximum values. The MCAP and SVT average values vary from -1.3942 and -3.3798 minimum to 352.15 and 135.79 maximum, respectively. The broad money ratio depicts a maximum value of 98.136 and minimum of 1.64113. The standard deviation values depicts that the MCAP with value 70.6911 deviates furthest from the mean while PHKAP with value 8.2771 deviates least from the average. The series skewness indicates that all the variables exhibit positive skewness. MCAP and SVT exhibit leptokurtic activities, while AGRVA, $M_{2} /$ GDP, PHKAP and LAB portray platokurtic characteristics. This implies that the mean values of MCAP and SVT lie above 3, while the average values of AGRVA, $M_{2} /$ GDP, PHKAP and LAB lie below 3 . All the variables are not normally distributed except PHKAP based on the Jarque-Bera probability. This could be justified by the macroeconomic environment changes of the individual emerging economies in Africa. The number of observations indicates that the data are balanced panel data.

\subsection{Unit root test estimates}

In Table 2, Levin et al. (2002) proposed tests using Levin, Lin and Chu, Im, Pesaran and Shin, Augmented Dickey Fuller (ADF)-Fisher Chi-square and Philip Peron (PP)-Fisher Chi-square tests utilized by Choi (2001) are applied for the panel unit root analysis. Applying Schwarz information criteria (SIC), automatic lag selection alongside an intercept without trend depicts the variables with I(1) integration orders. The unit root results forecast a long-run connection between stock market development variables and agricultural growth based on I(1) integrated order. This favours the used of fully modified and dynamic ordinary least square approaches since more variables are integrated of order one.

\subsection{Correlation analyses}

In Table 3, all the variables negatively correlate the agricultural value added to the GDP except labour which correlates positively with agricultural value added to the GDP in the African emerging economies. There is no indication of multicollinearity since a majority of the variables' coefficients are closer to zero than the estimated 0.7 threshold value above which evidence of strong correlation or collinearity exists. This is in accordance with Friendly (2002) and the interpretations of Anesthesia and Analgesia (2018).

\subsection{Residual cross-section dependence test}

To establish whether co-integration check is required in the analysis, the residual crosssectional dependence check is performed. The other motives for this test include omitted 


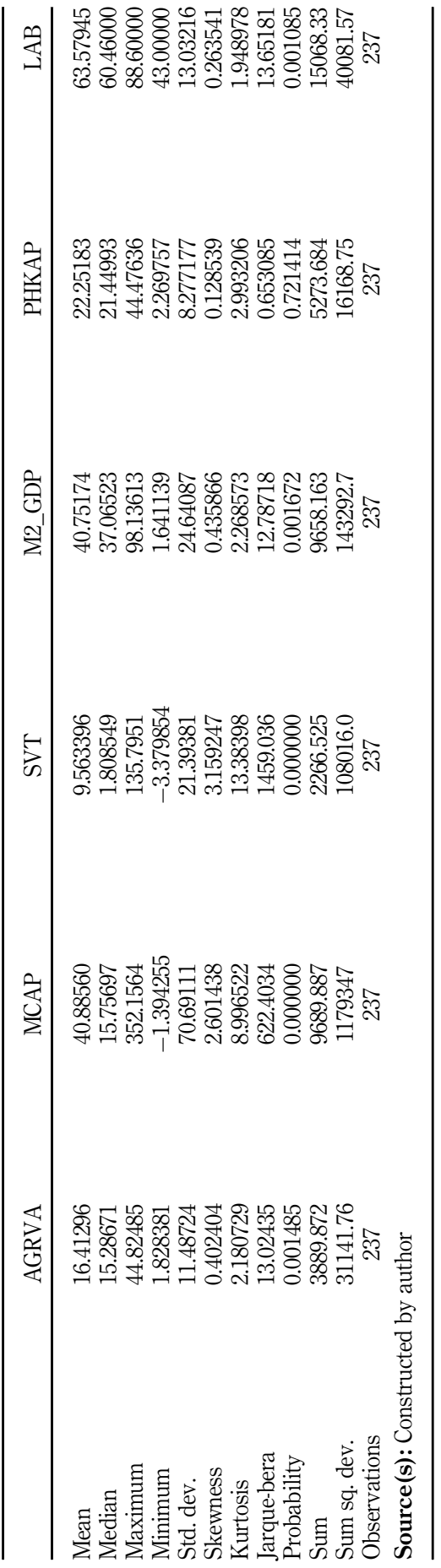

Stock market development

195

Table 1. Descriptive statistics 
JCMS

6,2

196

observed ordinary variables, unobserved ordinary variables, general residual interdependences and spatial spillover effects inherent in the estimation. The cross units' dependence requires a spatial spill over impact. This implies the economic integration could increase between the emerging economies in Africa. The long-term alliance of the variables is possibly predicted by the cross-sectional units' interdependences (Arouri El et al., 2013). The residual cross-sectional dependency test outcomes for the variables with $p$-values significance at $5 \%$ level are presented $n$ in Table 4 . The results reject the null hypothesis of no cross-sectional dependence among the variables in favour of the alternative given the strong statistical significant values of the three tests used. Hence, market capitalization, stock value traded, broad money supply ratio, physical capital and labour exhibit a long run common vitality.

\subsection{Johansen Fisher and Kao residual panel co-integration tests}

In Table 5, the co-integration tests between the explanatory variables and the explained variable are conducted using the Johansen-Fisher combined and Kao residual panel cointegration checks in accordance with Maddala and $\mathrm{Wu}$ (1999). The Johansen co-integration test presents six hypothesized co-integrating equations focused on the Trace and Max-Eigen statistic tests values. From the findings, the Trace and Max-Eigen tests reveal six cointegrating equations out of six panel hypothesized test equations since all the equations are

Table 2.

\begin{tabular}{lccccl}
\hline & Levin et al. & Im et al. & $\begin{array}{c}\text { ADF-Fisher chi- } \\
\text { square }\end{array}$ & $\begin{array}{c}\text { PP-Fisher chi- } \\
\text { square }\end{array}$ & $\begin{array}{l}\text { Integration } \\
\text { order }\end{array}$ \\
\hline AGRVA & $-14.0695^{* * * *}$ & $-14.8579^{* * *}$ & $186.897^{* * * *}$ & $213.831^{* * * *}$ & $\mathrm{I}(1)$ \\
MCAP & $-17.6886^{* * * *}$ & $-15.8558^{* *}$ & $165.003^{* * *}$ & $190.468^{* * * *}$ & $\mathrm{I}(1)$ \\
SVT & $-10.9064^{* * * *}$ & $-11.6407^{* * *}$ & $141.394^{* * * *}$ & $219.578^{* * *}$ & $\mathrm{I}(1)$ \\
M2_GDP & $-9.50977^{* * * *}$ & $-9.46625^{* * *}$ & $114.258^{* * *}$ & $137.352^{* * *}$ & $\mathrm{I}(1)$ \\
PHKAP & $-11.3931^{* * *}$ & $-11.4455^{* * *}$ & $138.499^{* * *}$ & $157.083^{* * * *}$ & $\mathrm{I}(1)$ \\
LAB & -0.46521 & $-3.60466^{* * *}$ & $46.2945^{* * *}$ & $41.5123^{* * *}$ & $\mathrm{I}(1)$
\end{tabular}

Unit root test estimates Source(s): Conceptualized by author: $(* * *)$ denotes $1 \%$, significance level

\begin{tabular}{|c|c|c|c|c|c|c|}
\hline & AGRVA & MCAP & SVT & M2_GDP & PHKAP & LAB \\
\hline AGRVA & 1.000000 & & & & & \\
\hline MCAP & -0.460511 & 1.000000 & & & & \\
\hline SVT & -0.356866 & 0.911457 & 1.000000 & & & \\
\hline M2_GDP & -0.412633 & 0.430910 & 0.480037 & 1.000000 & & \\
\hline PHK̄AP & -0.029072 & -0.203119 & -0.228237 & -0.576735 & 1.000000 & \\
\hline $\mathrm{LAB}$ & 0.541159 & -0.287125 & -0.276203 & -0.740428 & 0.438756 & 1.000000 \\
\hline \multicolumn{7}{|c|}{ Source(s): Author's assemblage } \\
\hline
\end{tabular}

Table 3.

Correlation analyses

\section{Test}

Breusch-pagan LM

Table 4.

Residual cross-section dependence test
Pesaran scaled LM

Pesaran CD

Source(s): Author's assemblage: (***) represents $1 \%$ significance level

\section{Statistic}

165.3571 ***

$15.24489 * * *$

5.120638 *** 
statistically significant at $5 \%$ level. The findings unveiled that co-integration exists among the variables. Thus, the null hypothesis of no co-integration is not accepted. The Kao residual co-integration test results revealed a long-run association between the exogenous variables and the endogenous variable in the African emerging economies.

\subsection{Fully modified OLS (FMOLS) and dynamic OLS (DOLS) estimations}

In Table 6 the estimated results of the fully modified ordinary least square and dynamic ordinary least square techniques are illustrated. The pooled weighted regression method is employed to analyse the FMOLS and DOLS with no constant and trend. The results show that MCAP negatively and significant affects agricultural growth, while SVT positively affects agricultural growth in the FMOLS and DOLS approximation techniques. $M_{2} / \mathrm{GDP}$ and PHKAP influence agricultural growth negatively, while LAB impacts AGRVA positively in the FMOLS and DOLS estimation methods. A percentage increase in market capitalization decreases agricultural growth in the FMOLS and DOLS estimation methods by 12.1 and $11.1 \%$, respectively. This implies that a unit increase in stock value traded raises agricultural growth by 24.0 and $25.1 \%$ in the FMOLS and DOLS estimation methods, respectively. The findings divulge a long-term affiliation between stock market development and agricultural growth in African emerging economies. These results corroborate the findings of Ayodeji and Ajala (2018) and Ini and Eze (2019). Nonetheless, the findings are contrary to the results of Karim and Chaudhary (2017).

\begin{tabular}{lcc}
\hline Hypothesized No. of CE(s) & Fisher stat.* (trace test) & Fisher stat.* (max-eigen test) \\
\hline None & $287.0^{* * * *}$ & $167.7^{* * *}$ \\
At most 1 & $129.3^{* * *}$ & $85.70^{* * *}$ \\
At most 2 & $76.56^{* * *}$ & $54.24^{* * *}$ \\
At most 3 & $54.09^{* * *}$ & $34.67^{* * *}$ \\
At most 4 & $34.87^{* * *}$ & $28.55^{* *}$ \\
At most 5 & $29.94^{* * *}$ & $29.94^{* *}$ \\
Kao residual co-integration test & & $t$-Statistic \\
ADF & & $-1.665163^{* *}$
\end{tabular}

Stock market development

Table 5. Johansen Fisher and Kao residual panel cointegration tests

\begin{tabular}{lcc}
\hline Variables & FMOLS & DOLS \\
\hline MCAP & $-0.120773^{* * * *}(-4.177682)$ & $-0.110681^{* * * *}(-4.497695)$ \\
SVT & $0.239574 * *(2.456153)$ & $0.250892^{* * * *}(3.069042)$ \\
M2GGDP & $-0.056726^{*}(-1.727675)$ & $-0.113983^{* * *}(-2.594691)$ \\
PHKAP & $-0.577654^{* * * *}(-4.812136)$ & $-0.795682^{* * * *}(-3.698983)$ \\
LAB & $0.532290^{* * * *}(11.02542)$ & $0.652856^{* * *}(8.981402)$ \\
No. of countries & 9 & 9 \\
Observation & 215 & 156 \\
Hausman test & 5.879781 & 5.879781 \\
$R$-squared & 0.547207 & 0.547207 \\
Adjusted $R$-squared & 0.538582 & 0.538582 \\
SE. of regression & 7.807415 & 7.807415 \\
Long-run variance & 153.5994 & 153.5994
\end{tabular}

Source(s): Author's assemblage: $(* * *),(* *)$ and $\left({ }^{*}\right)$ represent 1,5 and $10 \%$ significance levels, respectively; $t$-statistics in parentheses
Table 6.

Fully modified OLS (FMOLS) and dynamic OLS (DOLS) estimations 
JCMS

6,2

198

\subsection{Pairwise Dumitrescu Hurlin panel causality tests}

Table 7 demonstrates the results of the causation between the stock market development variables and the agricultural value added to the GDP. Unidirectional causality flows from AGRVA to MCAP, SVT and $M_{2} / \mathrm{GDP}$, while bidirectional causality navigates between LAB and AGRVA. An inconclusive direction of causality exists between PHKAP and AGRVA. The unidirectional results are in line with the findings of Offum and Ihuoma (2018). The bidirectional outcomes validate the findings of Bashorun and Bakare-Aremu (2013), Ibi et al. (2015).

\section{Conclusion and policy implications}

This study examines the causation between stock market development and agricultural growth in African emerging economies from 1990 to 2020, employing annual secondary data gleaned from world development indicators database. The agricultural value added to the GDP proxies agricultural growth as the endogenous variable, while the exogenous variables are market capitalization, stock value traded and money supply ratio which measure stock market development. Labour and physical capital serves as control variables. The Johansen Fisher and Kao residual panel co-integration tests findings unveil a long term bond between the series. The fully modified ordinary least square and dynamic ordinary least square methods findings disclose that MCAP negatively affects agricultural growth, while SVT positively affects agricultural growth in the FMOLS and DOLS techniques. This indicates that the development of stock markets size in the African emerging economies is costly. $M_{2} /$ GDP and PHKAP impact agricultural growth negatively, while LAB affects AGRVA positively in the FMOLS and DOLS methods. The causality tests findings unveil bidirectional causality between LAB and AGRVA with unidirectional causality flows from AGRVA to MCAP, SVT and $M_{2} / \mathrm{GDP}$.

The findings suggest that the governments should promote agricultural growth initiatives and strategies which would stimulate stock market development in the long term. Also, effective methods to encourage credit flow and liquidity stream to agricultural enterprises through the stock markets' intermediation should be promoted applying aggressive policy which eliminate the bottlenecks undermining credit flow to the agricultural sector. The policy makers and regulatory authorities should implement policies which attract investors to the agricultural sector and encourage companies' listing in the countries' stock exchange markets. The governments of African emerging economies should expand funding into the capital market which considerably boosts economic growth through agricultural value added. Thus, policies that encourage investors' confidence via the institutions and stock market development frameworks should be applied.

\begin{tabular}{llll}
\hline Causality flow & W-Stat & Remark & Direction \\
\hline MCAP to AGRVA & 0.98877 & No causality & Unidirectional \\
AGRVA to MCAP & $3.87982^{* * * *}$ & Causality & \\
SVT to AGRVA & 0.69798 & No causality & Unidirectional \\
AGRVA to SVT & $2.84555^{* * *}$ & Causality & Unidirectional \\
M2_GDP to AGRVA & 1.34453 & No causality & No direction \\
AGRVA to M2_GDP & $3.12735^{* * *}$ & Causality & Bidirectional \\
PHKAP to AGRVA & 1.51392 & No causality & No causality \\
AGRVA to PHKAP & 1.88944 & Causality & Causality \\
LAB to AGRVA & $4.80233^{* * *}$ & $2.34953^{* *}$ &
\end{tabular}

Table 7.

Pairwise Dumitrescu Hurlin panel causality tests 


\section{References}

Abdulahi, S.A. (2005), Capital Market Performance and Economic Development in Nigeria: An Empirical Analysis, Paper Presented at a Seminar of the Department of Business Administration, Bayero University Kano.

Abeka, M.J., Andoh, E., Gatsi, J.G. and Kawor, S. (2021), "Financial development and economic growth nexus in SSA economies: the moderating role of telecommunication development", Cogent Economics and Finance, Vol. 9, pp. 87-102.

Abera, W.H., Gouder, S., Sheik, M. and Booth, R. (2019), "Impacts of stock market performance on firms' growth: with reference to South Africa”, Financial Markets, Institutions and Risks, Vol. 3 No. 1 , pp. 50-62.

Adelman, I. (1984), "Beyond export led growth”, World Development, Vol. 12 No. 9, pp. 937-949.

Agbaeze, K. and Onwuka (2013), "Boosting the financing of agriculture in Nigeria: the capital market option”, Research on Humanities and Social Sciences, Vol. 3 No. 13, pp. 113-126.

Akerlof, G.A. (1970), "The market for lemons: quality uncertainty and the market mechanism", Quarterly Journal of Economics, Vol. 84 No. 3, pp. pp488-500.

Akerlof, G., Spence, M. and Stiglitz, J. (1970), Market with Asymmetric Information: A Nobel Prize for Asymmetric Information: The Economic Contributions of George Akerlof, Michael Spence and Joseph Stiglitz, Nobel Prize Committee, New York.

Alile, H.I. and Anao, A. (1986), The Nigerian Stock Market in Operation, Jeromelaiho and Associate Limited, Lagos.

Anesthesia and Analgesia (2018), Correlation Coefficients: Appropriate Use and Interpretation, Vol. 126 No. 5, pp. 1763-1768.

Arouri El, H.M., M'saddek, O., Nguyen, M.E.A., Ameur, H.B., Jawadi, N., Jawadi, F. and Louhichi, W. (2013), "Market structure and the cost of capital; Economic modelling", Elsevier, Vol. 31 C, pp. 664-671.

Arrow, K.J. (1963), "Uncertainty and the welfare economics of medical care", The American Economic Review, Vol. 53 No. 5, pp. 941-973.

$\mathrm{Au}$ (2003), Maputo Declaration on Agriculture and Food Security, African Union, Maputo.

$\mathrm{Au}$ (2014), OAU/AU Treaties, Conventions, Protocols \& Charters, African Union, Malabo.

Ayodeji, E.A. and Ajala, R.B. (2018), "Capital market performance and economic growth in Nigeria (1984-2016)", Journal of Advances in Social Science and Humanities, Vol. 4 No. 11, pp. 362-378.

Ayodeji, E.A. and Ajala, R.B. (2019), "Capital market performance and sectoral output growth in Nigeria (1984-2018)", Journal of Advances in Social Science and Humanities, Vol. 5 No. 9, pp. 1033-1062.

Baltagi, A. and Badi, S. (2012), Econometric Analysis of Panel Data, John Wiley \& Sons, Hoboken.

Bashorun and Bakare-Aremu (2013), "Capital market development and economic growth: evidence from Nigeria", International Journal of Humanities and Social Science Invention, Vol. 2 No. 12 , pp. I-13.

Beck, T. and Levine, R. (2004), "Stock markets, banks and growth; Panel evidence", Journal of Banking and Finance, Vol. 28 No. 3, pp. 423-442.

Binswanger, H.P. and Deininger, K. (1997), "Explaining agricultural and agrarian policies in developing countries", Journal of Economic Literature, Vol. 35, pp. 1958-2005.

Breusch Trevor, S. and Adrian, R.P. (1980), "The Lagrange multiplier test and its applications to model specification in econometrics", The Review of Economic Studies, Vol. 47, pp. 239-253.

Choi (2001), "Unit root test for panel data", Journal of International Money and Finance, Vol. 20 No. 2, pp. 249-272. 
JCMS

6,2

Chukwuemeka, A. and Boma-Oruwari, T.A. (2021), "Financial market development and aggregate stock price of quoted firms in Nigeria stock market", International Journal of Business and Law Research, Vol. 9 No. 2, pp. 146-168, April-June, 2021.

Diao, X., Hazell, P., Resnick, D. and Thurlow, J. (2007), The Role of Agriculture in Development, Implications for Sub-Saharan Africa, International Food Policy Research Institute, NW Washington, D.C, USA, Vol. 2033.

Edame, G.E. and Okoro, U. (2013), "The impact of capital market on economic growth in Nigeria", Public Policy and Administration Research, Vol. 3 No. 9, pp. 7-15.

Ekezie, E.S. (2002), The Elements of Banking: Money, Financial Institutions and Markets, Africana-Fep Publishers Limited, Onitsha Nigeria.

Eze, O.M., Atuma, E. and BigBen, O. (2019), "Stock market liquidity and manufacturing sector performance: evidence from Nigeria (1981-2017)", Journal of Humanities and Social Science, Vol. 24 No. 4, pp. 13-22.

FAO (2018), The State of Food and Agriculture 2017: Leveraging Food Systems for Inclusive Rural Transformation, FAO, Rome.

FAO (2019), The State of Food Security and Nutrition in the World; Building Climate Resilience for Food Security and Nutrition, FAO, Rome.

Friendly, M. (2002), The American Statistician: Exploratory Displays for Correlation Matrices, Vol. 56 No. 4, pp. 316-324.

Ghosh, P., Mookherjee, D. and Ray, D. (2000), "Credit rationing in developing countries: an overview of the theory", Readings in the Theory of Economic Development, Vol. 7, pp. 383-401.

Hayami, Y. and Ruttan, V.W. (1985), Agricultural Development: An International Perspective, John Hopkins Press, Baltimore, MD, 1971, p. 367.

Hossfeld, O. (2016), Equilibrium Real Effective Exchange Rates and Real Exchange Rate Misalignments, Time Series vs. Panel Estimates FIW working paper No. 65.2010.

Ibi, E.E., Joshua, N.J., Eja, B.R. and Oluwatunbosun, H.U. (2015), “Capital market and industrial sector development in Nigeria-An empirical investigation”, European Journal of Accounting, Auditing and Finance Research, Vol. 3 No. 6, pp. 63-79.

Ikikii, S.M. and Nzomoi, J.N. (2013), "An analysis of the effects of stock market development on bidding ROSCAs", Department of Economics, Cornell University Journal of Policy and Development Studies, Vol. 9 No. 5, pp. 24-47.

Im, K.S., Pesaran, M.H. and Shin, Y. (2003), "Testing for unit roots in heterogeneous panels”, Journal of Econometrics, Vol. 115 No. 1, pp. 53-74.

IMF (2020), World Economic Outlook, October 2020; A Long and Difficult Ascent, IMF, Washington, DC.

Inagaki, K. (2010), "Income inequality and the suicide rate in Japan: evidence from co-integration and LA-VAR”, Journal of Applied Economics, Vol. XIII No. 1, pp. 113-133.

Ini, S.U. and Eze, O.R. (2019), "Implications of stock market efficiency on Nigerian manufacturing sector performance, 1985-2017”, Global Advanced Research Journal of Management and Business Studies, Vol. 8 No. 2, pp. 16-24.

Karim, S. and Chaudhary, G.M. (2017), "Effect of stock market development on economic growth of major South Asian and East Asian economies: a comparative analysis", Journal of Business Studies Quarterly, Vol. 8 No. 3, pp. 81-88.

Khetsi, Q.S. and Mongale, I.P. (2015), "The impact of capital markets on the economic growth in South Africa", Journal of Governance and Regulation, Vol. 4 No. 1, pp. 154-163.

Klonner, S. and Rai, A.S. (2005), Adverse Selection in Credit Markets: Evidence from South Indian Bidding ROSCAs, Department of Economics, Cornell University, Ithaca, NY.

Levin, A., Lin, C.F. and Chu, C.S. (2002), "Unit root tests in panel data: asymptotic and finite sample properties", Journal of Econometrics, Vol. 108, pp. 1-24. 
Maddala, G.S. and Wu, S. (1999), "A comparative study of unit root tests with panel data and a new simple test", Oxford Bulletin of Economics and Statistics, Vol. 61 No. S1, pp. 631-652.

Makki, S.S. and Somwaru, A. (2004), "Impact of foreign direct investment and trade on economic growth: evidence from developing countries", American Journal of Agricultural Economics, Vol. 86 No. 3, pp. 795-801.

Musara, M. and Olawale, F. (2012), "Perceptions of start-up small and medium sized enterprises (SMES) on the importance of business development services providers on improving access to finance in South Africa”, Journal of Social Science, Vol. 30 No. 1, pp. 31-41.

Obiakor, R.T. (2016), "Does capital market development Spur economic growth?: a look at Africa's largest economy”, The International Journal of Social Sciences and Humanities Invention, Vol. 3 No. 7, pp. 2397-2406.

Offum, P.F. and Ihuoma, C.E. (2018), "Capital market and industrial performance nexus: empirical evidence from Nigeria", The Nigeria Journal of Economic and Social Studies, Vol. 60 No. 3, pp. 2-16.

Okoye, V.O. and Nwisienyi, K.J. (2013), "The capital market contributions towards economic growth and development; the Nigerian experience", Global Advanced Research Journal of Management and Business Studies, Vol. 2 No. 2, pp. 120-125.

Olowe, R.A. (2011), "Nigerian stock exchange and economic development", Manager Journal, Vol. 14 No. 1, pp. pp14-38.

Osakwe, C.I. and Ananwude, A.C. (2017), "Stock market development and economic growth: comparative evidence from two emerging economies in Africa-Nigeria and South Africa", Archives of Current Research International, Vol. 11 No. 1, pp. 1-15.

Osamwonyi, I.O. and Kasimu, A. (2013), "Stock market and economic growth in Ghana, Kenya and Nigeria”, International Journal of Financial Research, Vol. 4 No. 2, pp. 83-98.

Owen, M.A. (2020), "Stock market development and economic growth: empirical evidence from an institutional impaired economy", International Journal of Financial Research, Vol. 11 No. 5, p. 2020.

Owusu, E.L. (2018), "Stock market development and economic growth: new evidence from South Africa", Open Journal of Economics and Commerce, Vol. 1 No. 2, 1971, pp. 42-52.

Pardy, R. (1992), "Institutional reform in emerging securities market", Policy Research Working Papers (Financial Policy and Systems), No. 907, World Bank, pp. 3-28.

Pesaran, M.H. (2004), "General diagnostic tests for cross section dependence in panel”, CESifo Working paper series 1229, Cambridge, UK.

Philips, P.C.B. and Hansen, B.E. (1990), "Statistical inference in instrumental variables regression with I(1) processes", Review of Economic Studies, Vol. 57, pp. 99-125.

Rothschild, M. and Stiglitz, J. (1976), "Equilibrium in competitive insurance markets: an essay on the economics of imperfect information", Quarterly Journal of Economics, Vol. 90 No. 4, pp. 75-90.

Rukhsana, K. and Shahbaz, M. (2008), "Remittances and poverty nexus: evidence from Pakistan", Oxford Business and Economics Conference Program.

Sehrawat, M. and Giri, A.K. (2017), "A sectoral analysis of the role of stock market development on economic growth: empirical evidence from Indian economy", Sage Business Review, Vol. 18 No. 4, pp. 911-923.

Shittu, I. (2012), "Financial intermediation and economic growth in Nigeria", British Journal of Arts and Social Sciences, Vol. 4 No. 2, pp. 164-178.

Singer, H. (1979), Policy Implications of the Lima Target, Industry and Development, Vol. 3, pp. 17-22.

Stiglitz, J. (1998), "The role of the financial system in development", Presentation at the Fourth Annual Bank Conference on Development in Latin America and the Caribbean (LACABCDE), San Salvador, ElSalvador, June 29, 1998.

Stock market development 
JCMS

6,2

Stock, J.H. and Watson, M. (1996), "Evidence of structural instability in macroeconomic time series relations", Journal of Business and Economic Statistics, Vol. 14, pp. 11-30.

Simtowe, F., Zeller, M. and Phiri, A. (2006), "Determinants of moral hazard in microfinance: empirical evidence from joint liability lending schemes in Malawi”, 2006 International Association of Agricultural Economists Conference, Gold Coast, Australia, Aug. 12, 2006.

Uwajumogu, N.R., Ogbonna, I.C., Chijioke, G. and Agwu, S.V. (2013), "The growth-inducing impact of Nigeria capital market on agricultural sector", Journal of Humanities and Social Science, Vol. 16 No. 6, pp. 63-71.

World Bank (2018), Breaking Down the Barriers to Regional Agricultural Trade in Central Africa, World Bank, Washington, DC.

World Bank (2020), World Development Report; Africa Agriculture Status Report 2020: Here Are the Major Highlights, World Bank, Washington, DC.

Zedillo, Y.E. (2015), The Past Decade and the Future of Globalisation; BBVA Open Mind, Yale Centre for the Study Globalisation, New Haven.

\section{Further reading}

Diao, X., Breisinger, C., Kolavalli, S., Quinones, E. and Alpuerto, V. (2010), The Economic Importance of Agriculture for Sustainable Development and Poverty Reduction in Ghana; Case Study Report Contributed to the OECD Global Forum on Agriculture, Nov. 2010, Washington, DC.

Himanshu, A.A. and Hunt, L.C. (2007), "Electricity demand for Sri Lanka: a time series analysis; Surrey energy economics discussion paper series, No. 118”, Energy, Vol. 33 No. 5, pp. 724-739.

IMF (2019), Country Report No. 19/2 Central African Economic and Monetary Community (CEMAC), December 2018, IMF, Washington, DC.

\section{Corresponding author}

Chi Aloysius Ngong can be contacted at: aloyzih@yahoo.com

For instructions on how to order reprints of this article, please visit our website:

www.emeraldgrouppublishing.com/licensing/reprints.htm

Or contact us for further details: permissions@emeraldinsight.com 